\title{
VERIFICATION OF THE PELEG AND NORMAND EQUATION AT VARIED LOADS AND MOISTURE DURING STRESS RELAXATION OF WHEAT
}

\author{
Grzegorz Łysiak* ${ }^{*}$ Ryszard Kulig, Monika Wójcik \\ Department of Food Engineering and Machines, University of Life Sciences in Lublin, Poland \\ Grzegorz Łysiak, ORCID 0000-0002-4942-3050; Ryszard Kulig ORCID 0000-0003-0994-8140; \\ Monika Wójcik ORCID 0000-0002-2128-0334
}

*Corresponding author: e-mail: grzegorz.lysiak@up.lublin.pl

\begin{tabular}{|c|c|}
\hline ARTICLE INFO & ABSTRACT \\
\hline $\begin{array}{l}\text { Article history: } \\
\text { Received: August } 2019 \\
\text { Received in the revised form: } \\
\text { September } 2019 \\
\text { Accepted: September } 2019\end{array}$ & \multirow{2}{*}{$\begin{array}{l}\text { Wheat kernel is made up of structures of different apparent viscosities } \\
\text { with varied ability to withstand stress and dissipate strain energy. Its } \\
\text { complex mechanical behaviour determines technological susceptibility } \\
\text { and is important for wheat quality assessment. The aim of the study was } \\
\text { the examination of the Peleg and Normand model to characterize the } \\
\text { overall stress relaxation behaviour of wheat kernel at varying loading } \\
\text { conditions. The relaxation experiments were made with a help of a uni- } \\
\text { versal machine Zwick Z020 in compression at four distinct initial load } \\
\text { levels, i.e., 20, 30, 40, and } 50 \mathrm{~N} \text {. The measurements were made for in- } \\
\text { tact wheat kernels at seven levels of moisture content. Relaxation char- } \\
\text { acteristics were approximated with the help of Peleg and Normand for- } \\
\text { mula. An interactive influence of the load level and moisture on Peleg } \\
\text { and Normand constants have been confirmed. The initial loading level } \\
\left.\text { had none or only slight effect on the model coefficients ( } Y(t), k_{1} \text { and } k_{2}\right) \text {. } \\
\text { The parameters of the Peleg and Normand model decreased with the } \\
\text { increase of water content in kernels. For moist kernels, a higher amount } \\
\text { of absorbed compression energy was relaxed, since less energy was } \\
\text { necessary to keep the deformation at a constant level. }\end{array}$} \\
\hline $\begin{array}{l}\text { Key words: } \\
\text { wheat, } \\
\text { stress relaxation, } \\
\text { initial load, } \\
\text { compression, } \\
\text { Peleg and Normand }\end{array}$ & \\
\hline
\end{tabular}

\section{Introduction}

Food products are complex showing a wide range of different mechanical behaviors (Gunasekaran and Ak, 2000). Even if some of them could be well described based on simplified models such as the ideal solid (elastic), the ideal liquid (viscous), the ideal plastic and their combination, most food products are neither pure liquids nor ideal solids. In addition, their rheological characteristics depend on many factors such as moisture, level and rate of deformation, temperature and others (Khazaei and Mann 2004; Lewicki, 2004).

Many models have been advanced to analyze viscoelastic properties of foods. For this purpose, theoretical rheology gives us mechanical analogues. They are composed of springs (considered ideal solids) and dashpots (representing ideal fluids) combined in different ways. The most commonly used mechanical analogues are Maxwell, Kelvin-Voigt and standard 
linear models. There are also many modifications and equations such as Peleg and Normand formula.

The Peleg and Normand model is a simple, quick and effective method to handle stress relaxation data (Wu et al., 2012). It is easy to perform and to analyse the results. The equation has been proven to be valid in many individual cases, and apart from its mathematical convenience, it has been proven to be sensitive enough to account for changes that occur during deformation. Significant correlations were found between textural characteristics and stress relaxation parameters for raw, dried and cooked noodles (Hatcher et al., 2008; Shiau et al., 2012; Shiau and Chang 2013). Lewicki and Łukaszuk (2000) analyzed the changes of rheological properties of apple tissue undergoing convective drying. They concluded that the rheological properties based on the Peleg model strongly correlate to the moisture content and reflect changes from distributions of components and structure. On the other hand, Buňka et al., (2013) examined changes during ripening of Edam cheese and found that only the parameter expressing the extent of material relaxation provided an adequate description of the actual changes. The initial rate at which the stress relaxes provided no relevant description. Also, Singh et al., (2006) and Filipčev (2014) support the statement on the inadequacy of parameter $k_{1}$ to follow the textural changes or in differentiating various food products. Though, this parameter has not been considered as a reliable parameter to discern viscoelastic properties, some authors found that it differed among various samples such as cooked spaghetti (Sozer et al., 2008), cooked Asian noodles (Hatcher et al., 2008) or wheat breads (Mandala et al., 2007). According to Sozer et al. (2008), the Peleg and Normand equation is a good alternative to Maxwell models. Moreover, they also noted that at large deformations, Maxwell models did not fit very well to their data for spaghetti, and the linearized version of the Peleg and Normand model helped to overcome this problem. Thus, there are still different opinions, and many particular cases must be treated individually.

Most biological materials exhibit a non-linear viscoelastic behavior at large (e.g., 5\% strain or greater) deformations (ASAE, 2006) and more studies have reported the rheological properties evaluated under large strains. It results from the fact that in real processing condition, large deformations (beyond the elastic region) occur, resulting in the expected fracture of the material (Karim et al., 2000). Large deformation creep and relaxation tests have been conducted for different foods. Analysis of relaxation curves for raisins (Lewicki and Spiess, 1995) shows that a proportion of the unrelaxed stress is larger if the developed stress is higher. According to Guo et al., (2016), higher applied stress can result in a higher relaxation speed. The strain level also effected the constants of the Peleg and Normand model for a bulk relaxation test of Jatropha curcas seeds (Herak et al., 2015), steamed bread (Wu et al., 2012) which significantly decreased at larger strains. Karaman et al., (2016) indicated slightly more elastic behavior of cheese at higher compression levels. The effect of initial deformation of buckthorn berries has been studied by Khazaei and Mann (2004). According to this report the deformation level had a definite effect on the decay forces for Maxwell elements, whereas the effect on relaxation times was different for each element and not always ambiguous. Similarly, Bargale and Irudayaraj (1995) reported that the effect of the deformation level on relaxation time was consistent and did not show a clear trend. In addition, Faridi and Faubion (2012) following Shelef and Bousso (1964) state that under the conditions used, stress relaxation can be fairly independent of initial stress.

In summary, stress relaxation experiments can be used to study large deformations, and it is desirable to test the model in a wide range of deformation patterns. The aim of the study 
Verification of the peleg...

is determination of the influence of the initial loading level on relaxation characteristics described by the model of Peleg and Normand. The effect was examined for varying moisture content.

\section{Material and Methods}

Soft wheat (cultivar Belissa) originated from plant breeding station HR Smolice (harvest in 2015).

The methodology of sample preparation and basic procedures for determination of relaxation parameters were based on the previous studies presented in $\mathrm{Al}$ Aridhee and Łysiak (2015). Three $5 \mathrm{~g}$ samples of grains were dried in an oven at $130^{\circ} \mathrm{C}$ for over 2 hours, in accordance with the Polish standard PN-EN ISO 712: 2012. The water content in the samples was calculated according to the formula (wet basis):

$$
m_{i}=\frac{M_{w}-M_{d}}{M_{w}} \cdot 100 \%
$$

where:

$M_{w} \quad$ - mass of the sample before drying

$M_{d} \quad$ - mass of the sample after drying

In order to obtain samples with different moisture levels, i.e. 8, 10, 12, 14, 16, 18 and $20 \%$ (wet basis), a batch of known weight and humidity was dried at $40^{\circ} \mathrm{C}$ until reaching a level of $8 \%$ water content. The batch was subsequently divided into (seven) smaller samples and the required amount of water was added to each. The amount of water was calculated according to the basic mass balance equations.

The stress relaxation measurements were performed in the laboratory of the Department of Food Engineering and Machines. A universal testing machine Zwick Z020 was used for relaxation measurements. It was equipped with $0.1 \mathrm{kN}$ capture. Application of the $0.1 \mathrm{~N}$ capture with the accuracy grade $0.5 \%$, resulted in the precision of force measurement to $0.5 \mathrm{~N}$. The machine was operated by the firmware testXpert by Zwick (version 7.1). The measurements were made for seven above mentioned levels of the moisture content. Prior to the experiments the weight of each individual kernel was determined. The kernel of wheat was then placed with its ventral side on the bottom of machine's plate and then loaded axially until a required load level was obtained. The constant compression rate during the loading at $10 \mathrm{~mm} \cdot \mathrm{min}^{-1}$ was adjusted. The strain (deformation) of kernel was kept constant during next $300 \mathrm{~s}$. The decreasing value of loading force as a function of time was measured with the help of testXpert software at the frequency of $100 \mathrm{~Hz}$.

The experiments were conducted for four distinct initial load levels i.e., 20, 30, 40, and $50 \mathrm{~N}$. The maximum applied value corresponds to about half of the value of force causing kernel rupture (at ambient conditions). Twenty replications were performed for each moisture and load level. 


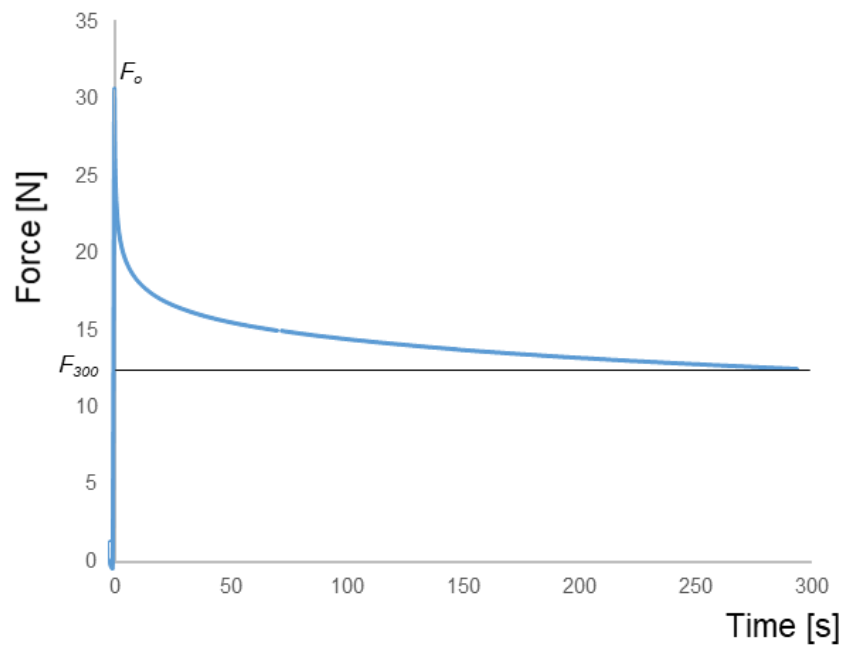

Figure 1. An example of relaxation characteristic of wheat kernel

Peleg and Normand (1983) suggested that stress relaxation data could be calculated as a normalized stress and fitted to the formula (2). The formula was used by many authors and depending on the assumptions made it is based on decay in stress, modulus or force. Force which was used in the study is also a valid criterion (Lysiak, 2007). Hence, relaxation of wheat kernel can be expressed in terms of force decay as:

$$
\frac{F_{o} t}{F_{o}-F_{t}}=k_{1}+k_{2} \mathrm{t}
$$

where:

$F_{\mathrm{o}} \quad-$ initial loading force at time $t=0 \mathrm{in},(\mathrm{N})$

$F_{t} \quad-$ force at relaxation time $t,(\mathrm{~N})$

$t \quad-$ time of relaxation, (s)

$k_{1}$ and $k_{2}$ - constants; the reciprocal of $k_{1}$ determines the initial decay rate, and $k_{2}$ is the hypothetical value of the asymptotic normalized force

The decay parameter $Y(t)$ was calculated according to:

$$
Y(t)=\frac{F_{o}}{F_{o}-F_{(300)}}
$$

where:

$F_{(300)}-$ is the force established at $300($ s)

$K_{1}$ indicates how fast the material in question is relaxing energy (at least initially). If the reciprocal of the $k_{1}$ represents the initial decay rate, then its value can be associated with a low rate of decay, indicating a pronounced elastic behaviour. A higher value of $k_{1}$ suggests a harder, more solid-like material that dissipates less energy, thus needing more force to be compressed (Guo et al., 1999). The parameter $k_{2}$ is the representative of the degree of solidity, 
Verification of the peleg...

and it varies between 1, for a material that is truly a liquid, to infinity, for an ideal elastic solid where the stress does not relax at all (Peleg, 1980).

The constants of the Peleg and Normand model were estimated by fitting the experimental data to the above formulas using Excel software. Experimental data were analyzed using Statistica, Dell Inc. (Dell, 2016) version 13. In all the analyses, the significance level at 0.05 was acquired.

\section{Results and Discussion}

The average weight of kernels for individual applied loads ranged from 0.0508 to 0.0525 $\mathrm{g}$. There were no statistically significant differences between the means $(\mathrm{p}=0.24)$. Significant differences were, however, observed for kernels with different water contents. In this case, the average weight of kernels increased from about 0.0487 to $0.0552 \mathrm{~g}$.

Figure 2 shows the effect of the initial loading level on the average values and the distribution of the decay parameter. The decay represents a rate of decline in the force as a result of relaxation. Very slight changes of the parameter were observed for the initial loads applied.
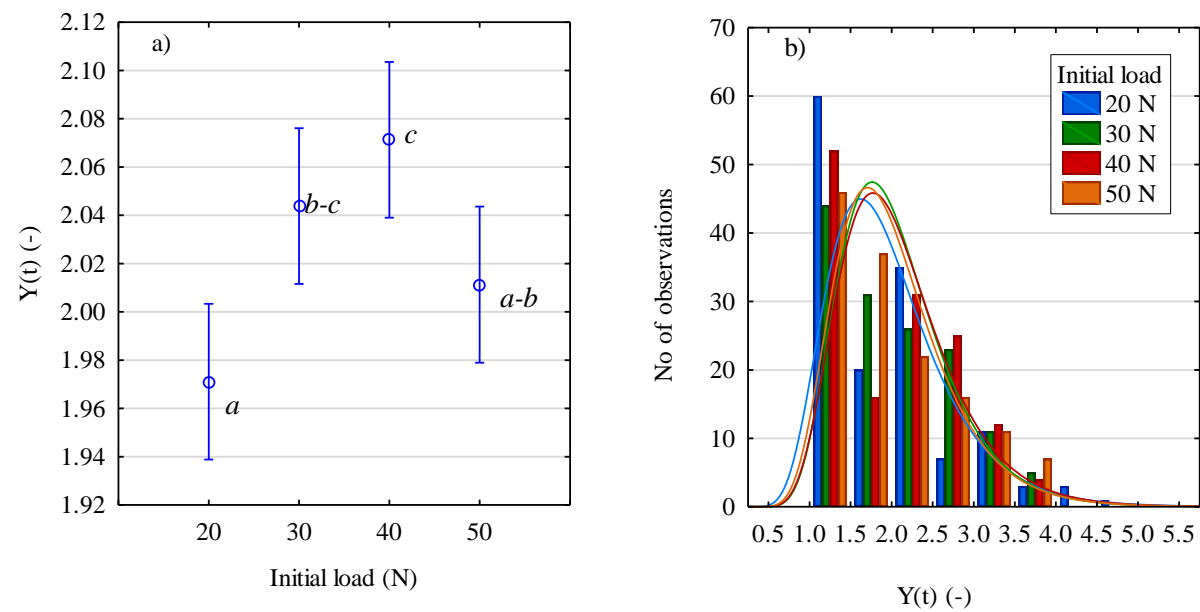

Figure 2. Influence of the initial loading level of wheat kernels on the force decay $Y(t)$; a-c -homogeneous groups

The averages ranged from 1.97 to 2.07 though, some means were statistically different. The observed small decrease in decay for $50 \mathrm{~N}$ loading might be caused by higher plastic deformation for moist kernels. Apart from the averages, variability of individual results represented by the scale parameter of the lognormal distributions included in Fig. $2 \mathrm{~b}$ was found to be also similar and not statistically dependent on the initial loading. If the parameter is large, then the distribution will be more spread out, if it is small then it is more concentrated. It ranged from 0.60 for $20 \mathrm{~N}$ to 0.67 for $40 \mathrm{~N}$ load. The twofold higher numbers of observations 
in the range of 1.0-1.5 were a reason of wheat softness at high moisture (at 18-20\%) and the fact that the decay tends to unity for more soft (liquid) materials.

Following the above results, one question arises, whether this low or lack of significance of initial load is equally valid for hard or soft materials (wheat). To answer this, the effect was tested at varied wheat softness resulting from changing moisture.

The effect of the moisture content on the force decay parameter $Y(t)$ is shown in Fig. 3a. A considerable decline in the decay was caused by the increasing moisture of kernels. Only for 18 and $20 \%$ the means were not statistically different, though the slower decline rate was observed above $16 \%$ of the water content. Figure $3 \mathrm{~b}$ shows the interaction between moisture and the initial load level. Analysis of variance demonstrated that an increase in both the moisture content and load caused significant differences in values of the decay parameter. The interactive effect between them was also significant. For relatively dry samples, the variability of the parameter caused by the changed initial load was much higher than that of moist samples.

For individual samples differing in moisture contents the effect of loading has not been confirmed, though significant effects of moisture, initial loads as well as interaction of the two factors (moisture content $\mathrm{x}$ initial load) on the parameter were statistically evidenced by variance analysis.
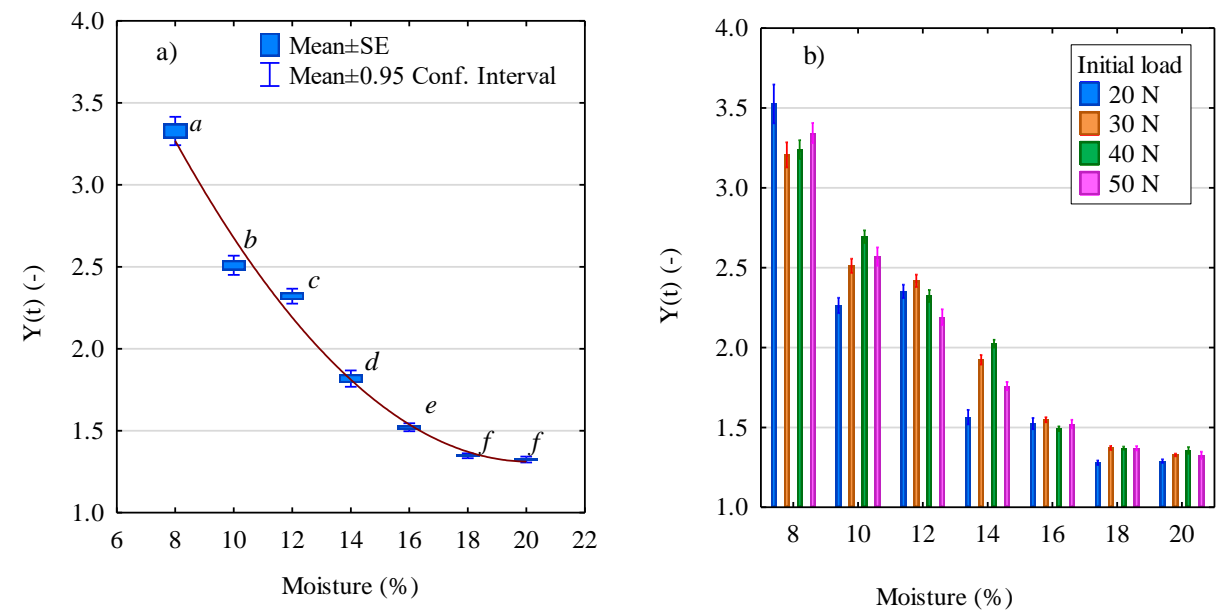

Figure 3. Influence of moisture content and loading level on the force decay based on Peleg and Normand equation: (a) average effect of moisture; (b) moisture $\times$ load interaction; a- $f$ - homogeneous groups

Figures 4a,b show the effect of the moisture content on the coefficients $k_{1}$ and $k_{2}$ of the model presented by Peleg and Normand. Values of $k_{1}$ and $k_{2}$ decreased with an increase in kernels' moisture content from about 35.0 to 10.6 and 2.9 to 1.28 , respectively. The means of the both constants have not differed between 18 and $20 \%$ of water contents. 
Verification of the peleg...

The overall effect of the load level on the coefficients $k_{1}$ and $k_{2}$ is presented in Fig. 4c-f. The two way-anova analysis confirmed interactive effect of loading level and moisture on values of the coefficients.
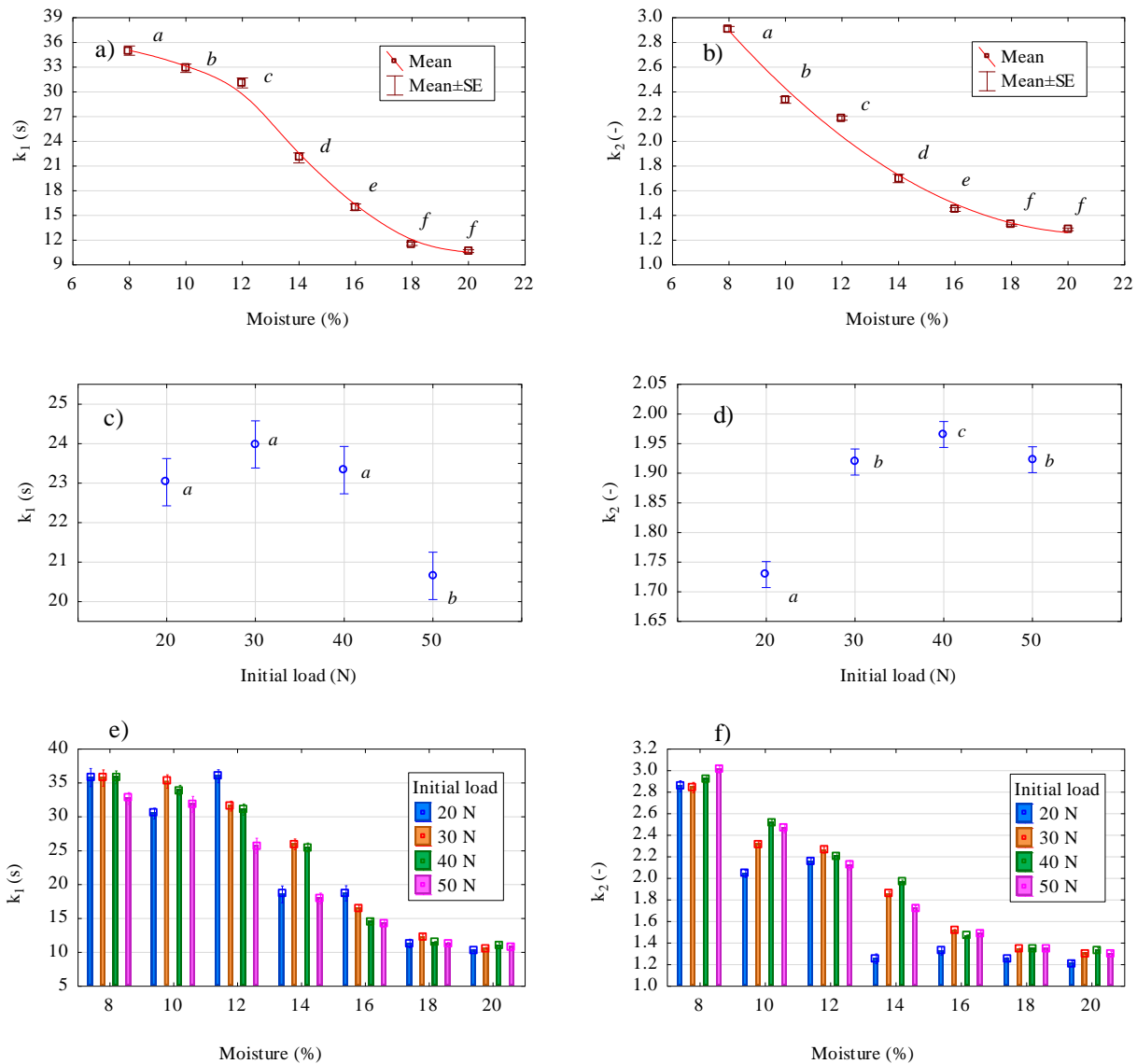

Figure 4. Influence of moisture $(a, b)$, loading level $(c, d)$ and their interaction $(e, f)$ on the coefficients of Peleg and Normand model; a-f - homogeneous groups

The distribution of individual results of the two analysed coefficients is presented in Fig. 5. Apart from the averages, the variability of results was similar and not statistically dependent upon the initial loading. The scale parameter of the normal distributions presented in figure ranged in 9.4-11.6 for $k_{1}$ and $0.59-0.61$ for $k_{2}$. The medians of $k_{1}$ ranged from 20.6 to 24.0 and $k_{2}$ from 1.72 to 1.92 . The histograms of the two coefficients for different load levels prove no effect of the factor. 
The strain level is postulated to be meaningful in relaxation experiments, however, no unique opinion in the research literature exists. Some reports show that initial stress can influence the amount of unrelaxed energy (Lewicki and Spiess, 1995), relaxations speed (Guo et al., 2016), which directly relates to constants of relaxation models (Khazaei and Mann, 2004, Herak et al., 2015, Karaman et al., 2016, Bargale and Irudayaraj, 1995). Lewicki and Spiess (1995) show that the proportion of the unrelaxed stress is larger if the developed stress is higher. Guo et al., (2016), state that a higher applied stress can result in a higher relaxation speed.
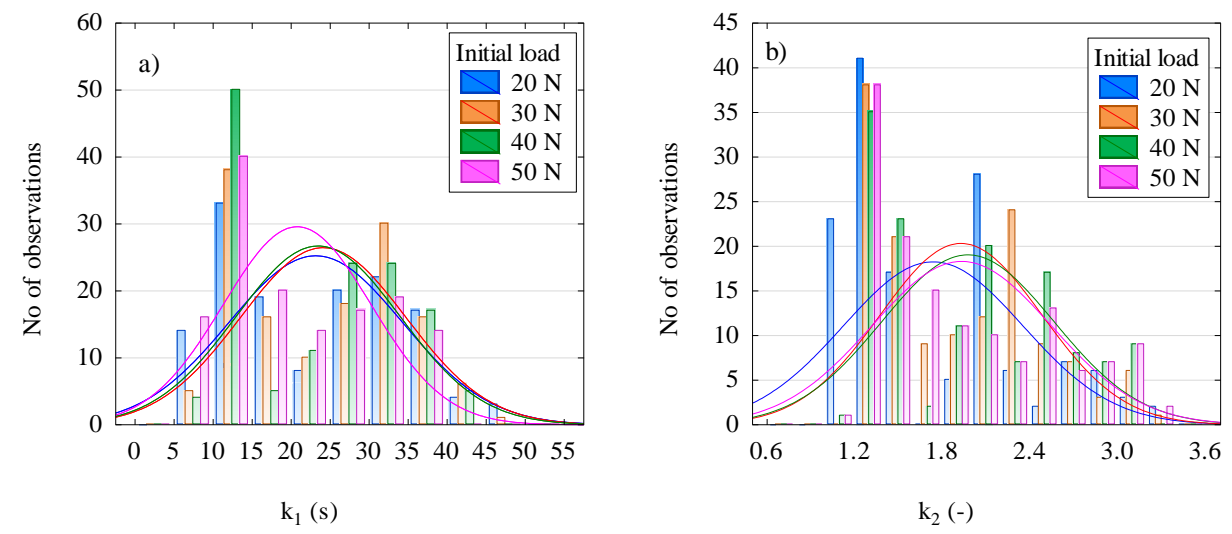

Figure 5. Histograms of the coefficients of Peleg and Normand model for different initial loading levels

The changes of all the obtained coefficient $Y(t), k_{1}$, and $k_{2}$ for studied wheat were very slight, and for any one of them no clear tendency was evidenced. The obtained results confirm those of Bargale and Irudayaraj (1995) on uni-axial compression of barley kernels, in which authors reported that the effect of the deformation level on the relaxation time was consistent and did not show a clear trend. Also, according to Faridi and Faubion (2012) and Shelef and Bousso (1964) stress relaxation can be fairly independent of the initial stress. Analysis of the research enables to state that many conclusions are true for specific circumstances only.

The observed decline of $Y(\mathrm{t})$ with moisture means that for dry kernels, a small amount of the initial force was relaxed, and the residual force established at $300 \mathrm{~s}$ was relatively high. In fact, as moisture content increased, the kernel becomes softer, and consequently, lower force is required to maintain a certain deformation level (Khazaei and Mann, 2005). Water influences rheological properties of food in liquid and solid state. In solid foods, water affects their response to force (Lewicki, 2004). Ozturk and Takhar (2017) explained a decreasing trend in values of relaxation constants as moisture level increased, with higher resistance to the relaxation of stresses at lower moisture levels. Samples with higher moisture content, relaxed faster than the ones with lower moisture as a result of the softening process. In the study it was observed that an increase in the moisture content of kernels caused the force to decrease more quickly. This is due to the increased plasticity of kernel and energy losses on non-recoverable deformations (Łysiak, 2007, Al Aridhee and Łysiak, 2015). In the model of 
Verification of the peleg...

Peleg and Normand, the coefficient $k_{1}$ represents the reciprocal of the initial decay rate. This means that its high value corresponds to a slower rate of force relaxation in the first few seconds. The coefficient $k_{2}$ represents the hypothetical value of the asymptotic normalized force (not relaxed). With an increase in moisture content, the residual force at the end of relaxation decreased and values of the coefficient declined similarly. This demonstrates that for moist samples much more energy was relaxed and less energy was necessary to keep the deformation at a constant level. The indicated results have been also reported in (Lysiak, 2007, Ozturk and Takhar, 2017). This study focused on examination of the effect of the initial load on model parameters. Irrespectively to the wheat softness no clear or very little effect (some interactions were observed) of the initial load on the model of Peleg and Normand was confirmed demonstrated.

\section{Conclusions}

The initial loading level had none or only slight effect on the parameters of Peleg and Normand model. The effect was similar, and it is not justified to state that anyone of the three analyzed parameters has been influenced the most. Very little differences between the means for the applied initial loads diminish the relevance of this factor for wheat relaxation experiments in the studied range of loads, and practical application of different loads will probably lead to similar results. It is reasonable to state that experiments at larger loads than applied here may lead to the development and propagation of cracks, making the relaxation tests more difficult to control and interpret. An interactive influence of moisture, and load level on Peleg and Normand constants has been statistically confirmed. The parameters $k_{1}$ and $k_{2}$ as well as the force decay $Y(t)$ decreased with the increase of the water content in kernels.

\section{References}

Al Aridhee, J., Łysiak, G. (2015). Stress relaxation characteristics of wheat kernels at different moisture. Acta Scientarum Polonorum, Technica Agraria, 14(3-4), 3-10.

ASAE 368.4. Compression Test of Food Materials of Convex Shape. (2006). St. Joseph, MI (USA): American Society of Agricultural and Biological Engineers, (ASABE), 554-556.

Bargale, P.C., Irudayaraj, J. (1995). Mechanical strength and rheological behavior of barley kernels. Internaional Journal of Food Science and Technology, 30(5), 609-623.

Buňka, F., Pachlová, V., Pernická, L., Burešová, I., Kráčmar, S., Lošák, T. (2013). The dependence of Peleg's coefficients on selected conditions of a relaxation test in model samples of edam cheese. Journal of Texture Studies, 44(3), 187-195.

Dell Inc. Dell Statistica (data analysis software system). Version 13. software.dell.com, 2016.

Faridi, H., Faubion, J.M. (2012). Dough rheology and baked product texture. Springer Science \& Business Media.

Filipčev, B.V. (2014) Texture and stress relaxation of spelt-amaranth composite breads. Food and Feed Research, 41(1), 1-9.

Gunasekaran, S., Ak, M.M. (2000). Dynamic oscillatory shear testing of foods-selected applications. Trends in Food Science and Technology, 11(3), 115-127.

Guo, L., Wang, D., Tabil, L.G., Wang, G. (2016). Compression and relaxation properties of selected biomass for briquetting. Biosystems Engineering, 148, 101-110.

Guo, Z., Castell-Perez, M.E., Moreira, R.G. (1999). Characterization of masa and low-moisture corn tortilla using stress relaxation methods. Journal of Texture Studies, 30(2), 197-215. 
Hatcher, D.W., Bellido, G.G., Dexter, J.E., Anderson, M.J., Fu, B.X. (2008). Investigation of uniaxial stress relaxation parameters to characterize the texture of yellow alkaline noodles made from durum and common wheats. Journal of Texture Studies, 39(6), 695-708.

Herak, D., Kabutey, A., Choteborsky, R., Petru, M., Sigalingging, R. (2015). Mathematical models describing the relaxation behaviour of Jatropha curcas L. bulk seeds under axial compression. Biosystems Engineering, 131, 77-83.

Karaman, S., Yilmaz, M.T., Toker, O.S., Dogan, M. (2016). Stress relaxation/creep compliance behaviour of kashar cheese: Scanning electron microscopy observations. International Journal of Dairy Technology, 69(2), 254-261.

Karim, A.A., Norziah, M.H., Seow, C.C. (2000). Methods for the study of starch retrogradation. Food Chemistry, 71(1), 9-36.

Khazaei, J., Mann, D. (2004). Effects of temperature and loading characteristics on mechanical and stress-relaxation behavior of sea buckthorn berries. Part 2. Puncture Tests. Agricultural Engineering International: CIGR Journal.

Khazaei, J., Mann, D. (2005). Effects of moisture content and number of loadings on force relaxation behavior of chickpea kernels. International Agrophysics, 19(4), 305-313.

Lewicki, P. (2004). Water as the determinant of food engineering properties. A review. Journal of Food Engineering, 61(4), 483-495.

Lewicki, P., Łukaszuk, A. (2000). Changes of rheological properties of apple tissue undergoing convective drying. Drying Technology, 18(3), 707-722.

Lewicki, P., Spiess, W.E. (1995). Rheological properties of raisins: Part I. Compression test. Journal of Food Engineering, 24(3), 321-338.

Łysiak, G. (2007). Influence in of moisture on rheological characteristics of the kernel of wheat. Acta Agrophysica, 9(1), 91-97.

Mandala, I., Karabela, D., Kostaropoulos A. (2007). Physical properties of breads containing hydrocolloids stored at low temperature. I. Effect of chilling. Food Hydrocolloids, 21(8), 1397-1406.

Ozturk, O.K., Takhar, P.S. (2017). Stress relaxation behavior of oat flakes. Journal of Cereal Science, 77, 84-89.

Peleg, M. (1980). Linearization of relaxation and creep curves of solid biological materials. Journal of Rheology, 24(4), 451-463.

Peleg, M., Normand, M.D. (1983). Comparison of two methods for stress relaxation data presentation of solid foods. Rheologica Acta, 22(1), 108-113.

Shelef, L., Bousso, D. (1964). A new instrument for measuring relaxation in flour dough. Rheologica Acta, 3(3), 168-172.

Shiau, S.Y., Chang, Y.H. (2013). Instrumental textural and rheological properties of raw, dried, and cooked noodles with transglutaminase. International Journal of Food Properties, 16(7), 14291441.

Shiau, S.Y., Wu, T.T., Liu, Y.L. (2012). Effect of the amount and particle size of wheat fiber on textural and rheological properties of raw, dried and cooked noodles. Journal of Food Quality, 35(3), $207-$ 216.

Singh, H., Rockall, A., Martin, C.R., Chung, O.K., Lookhart, G.L. (2006). The analysis of stress relaxation data of some viscoelastic foods using a texture analyzer. Journal of Texture Studies, 37(4), 383-392.

Sozer, N., Dalgic, A. C. (2007). Modelling of rheological characteristics of various spaghetti types. European Food Research and Technology, 225(2), 183-190.

Sozer, N., Kaya, A., Dalgic, A.C. (2008). The effect of resistant starch addition on viscoelastic properties of cooked spaghetti. Journal of Texture Studies, 39(1), 1-16.

Wu, M.Y., Chang, Y.H., Shiau, S.Y., Chen, C.C. (2012). Rheology of fiber-enriched steamed bread: stress relaxation and texture profile analysis. Journal of Food and Drug Analysis, 20(1), 133-142. 
Verification of the peleg...

\title{
WYKRZYSTANIE MODELU PELEGA I NORMANDA W BADANIACH WPLYWU WIELKOŚCI OBCIAূŻENIA I WILGOTNOŚCI ZIARNA PSZENICY NA WYNIKI RELAKSACJI NAPRĘŻEŃ
}

\begin{abstract}
Streszczenie. Ziarniak pszenicy składa się ze struktur o różnych własnościach lepko-sprężystych, różnej wytrzymałości i zdolności do rozpraszania energii odkształcenia. Jego złożone zachowanie mechaniczne determinuje podatność technologiczną i jest ważne dla oceny jakości ziarna. Celem badań była analiza zmienności parametrów modelu Pelega i Normanda w różnych warunkach obciążenia początkowego. Pomiary przeprowadzono przy wykorzystaniu uniwersalnej maszyny Zwick Z020. Zastosowano test jednoosiowego ściskania pojedynczych ziarniaków dla czterech początkowych poziomów obciążenia, tj. 20, 30, 40 i $50 \mathrm{~N}$. Badania wykonano dla siedmiu poziomów wilgotności. Charakterystyki relaksacyjne aproksymowano za pomocą równania Pelega i Normanda. Potwierdzono interaktywny wpływ poziomu obciążenia i wilgotności na stałe modelu. Początkowy poziom obciążenia nie miał żadnego lub wpływał tylko nieznacznie na współczynniki modelu $\left(Y(t), k_{1}\right.$ i $\left.k_{2}\right)$. Parametry modelu Pelega i Normanda spadały wraz ze wzrostem zawartości wody w ziarniakach. W przypadku wilgotnych ziarniaków relaksacji podlegała istotnie większa wartość zaabsorbowanej energii, potrzeba było też mniej energii aby utrzymać odkształcenie na stałym poziomie.
\end{abstract}

Słowa kluczowe: pszenica, relaksacja naprężeń, obciążenie początkowe, ściskanie, model Pelega i Normanda 